\title{
Putative Transcription Activator ORF50
}

National Cancer Institute

\section{Source}

National Cancer Institute. Putative Transcription Activator ORF50. NCI Thesaurus. Code C114493.

Putative transcription activator ORF50 (691 aa, $74 \mathrm{kDa}$ ) is encoded by the human herpesvirus 8 ORF50 gene. This protein plays a role in the initiation of the lytic phase of the viral life cycle. 